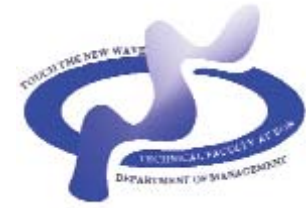

www.sjm06.com
Serbian

Journal

of

Management

\title{
FOREIGN INVESTMENT INFLOWS AND SECTORAL GROWTH PATTERN IN INDIA- AN EMPIRICAL STUDY
}

\author{
Mousumi Bhattacharya* \\ Army Institute of Management, Judges Court Road, Alipore \\ Kolkata, West Bengal, Pin: 700027, India
}

(Received 19. June 2012; accepted 3 December 2012)

\begin{abstract}
The paper aims to study the causal relationship between foreign investment inflows and sectoral growth pattern of the three main sectors namely primary, secondary and tertiary sector of the Indian economy during the post liberalization period (1996-97:Q1 to 2009-10:Q2). Using Granger causality test conducted in a multivariate VAR framework, bidirectional causality is observed between foreign investment inflows and secondary sector growth. It is seen that tertiary sector growth causes foreign investment inflows. Regression analysis is also done with the same dataset and it reveals that both secondary sector growth and tertiary sector growth have led to foreign investment inflows to the economy after 1990 reforms.
\end{abstract}

Keywords:Foreign investment inflows, Granger causality, Sectoral growth pattern

\section{INTRODUCTION}

Foreign investment is increasingly moving towards the service sector. Many countries are affected by the rise of service foreign investments and the broad based growth of service TNCs (Transnational Corporations). The efficiency productivity and supply capacity of the industries of host- countries can be enhanced either directly or indirectly through foreign investment in services, thereby benefiting the economy as a whole. An attempt has been made to examine the role of foreign investment inflows in promoting growth in the three main economic sectors, namely primary, secondary and tertiary. The growth effects of foreign investment inflows should be sector

\footnotetext{
* Corresponding author: mousumi.ma@gmail.com
}

DOI: $10.5937 /$ sjm8-2929 
specific as the productivity spillovers is widely believed to differ across sectors. The studies conducted so far either dealt with one sector without due consideration of all the three sectors of the Indian economy.

It is true that greater foreign investment inflows bring unambiguous benefits to the economy by generating employment, raising productivity, transferring foreign skills and technology and contributing positively to gross domestic product, gross fixed capital formation and balance of payments. Apart from stimulating export markets and producing foreign exchange revenue, foreign investment inflows can also contribute towards servicing debt repayments. About a third of total global exports are generated by the subsidiaries of MNCs (Multinational Corporations), which bring the vast portion of the FDI (foreign direct investments). The impact of foreign investments (both FDI and portfolio flows) depends on what form it takes and includes the type of foreign investments, sector, scale, duration and location of business and secondary impacts on the economy. In order to reap the benefits of foreign investments it is crucial to refocuss on the perspective apart from merely enhancing the availability of foreign investments and better application of foreign investments for attaining sustainable objectives.

Foreign investment inflow, where it generates and expands business enhances social development by stimulating employment, raising wages and activating declining market sectors. The benefits of foreign investment may only be felt by a small section of the population, e.g., where employment and training is given to the more educated. In case of wealthy elites or where there is urban emphasis wage differentials between income groups will be exacerbated. Cultural and social impacts may also occur when investment is particularly directed at non-traditional goods. Huge foreign currency inflows resulting from increased foreign investment inflows under a flexible exchange rate regime where market forces determine exchange rate, essentially result in appreciation of the local currency.

Apart from stimulating export markets and producing foreign exchange revenue, foreign investment inflows can also contribute towards servicing debt repayments. The impact of foreign investment inflows depends on what form it takes and includes the type of foreign investment inflows, sector, scale, duration and location of business and secondary impacts on the economy. In order to reap the benefits of foreign investment inflows it is crucial to refocus on the perspective apart from merely enhancing the availability of foreign investment inflows and better application of foreign investment inflows for attaining sustainable objectives. The impact of foreign investment inflows depends not only on the characteristics of the sectors but also on the linkage potential of these sectors with the rest of the economy.

\section{REVIEW OF LITERATURE}

It has been observed from the theoretical work of Findlay (1978) and Wang and Blomstrum (1992) that the importance of FDI as a conduit for transferring technology, relates to foreign investment inflows to manufacturing and services sector rather than primary sector. In his seminal book on economic development Hirschman (1958) described that FDI's potential to create linkages might vary across sectors. 
Hirschman (1958) also emphasized that not all sectors have the same potential to absorb foreign technology or to create linkages with the rest of the economy and noted that linkages are weak in agriculture and mining. Kokko (1994) observed that linkages vary across industries and agrues that spillovers could not be expected in all kinds of industries because foreign companies sometimes operate in "enclaves" that offer little scope for the local economy to benefit.

In UNCTAD World Investment Report (2001) it is argued that in the primary sector, the scope of linkages between foreign affiliates and local suppliers is often limited whereas the manufacturing sector has a broad variation of linkage intensive activities and in the tertiary sector the scope for dividing production into discrete stages and subcontracting out large parts to independent domestic firms is also limited. RodriguezClare (1996) shows that multinationals' intensive use of intermediate goods enhances production in host economies and with increased demand for inputs lead to a positive externality to other producers owing to an increase in variety. Greater variety of inputs seems to be more relevant to the manufacturing than to the agricultural sector. Alfaro (2003) conducted a study for the period 1981-1999 for 47 countries and came to the conclusion that FDI exerts an ambiguous effect on growth. FDI in the primary sector, tends to have a negative effect on growth while investment in manufacturing sector have a positive effect on growth of the economy. However, the effect on growth from the investment in the services sector is ambiguous.

In Indian context, Kathuria (2002) was the first to estimate the impact of foreign investment on productivity and spillovers to domestic firms in Indian manufacturing sector in the liberalization period 1989-90 to 1996-97. Chakraborty and Nunnenkamp (2008) assess the proposition that FDI in India will promote economic growth by subjecting industry specific FDI and output data to Granger causality tests with a panel cointegration framework and it turns out that the growth effects of FDI vary widely across sectors. Lo and Liu (2009) demonstrate why China has been so successful in disproportionately attracting foreign offshore manufacturing activities, while India has been engaged mainly in offshore service activities.

Assessing the role of foreign investment inflows in the context of various sectors (agriculture, industry, service) and examining output growth of those sectors (measured by share of those sectors in GDP) over the years have not been adequately examined at various sectoral levels during the post reform period in India. The number of empirical studies that cast the relationship of foreign investment inflows in different sectors and its impact on growth is limited due to unavailability of data. This paper aims to study the causal relationship between foreign investment inflows and sectoral growth pattern of the three main sectors namely primary, secondary and tertiary sector of the Indian economy during the post liberalization period (1996-97:Q1 to 200910:Q2).

\section{METHODOLOGY}

\subsection{Data Source}

This study used quarterly data on foreign investments inflows (both FDI and portfolio flows) in India covering the period 1996-97: Q1 to 2009-10:Q2. The shares of the three 
broadly classified sectors (primary, secondary and tertiary) in the quarter- wise GDP estimates at constant (1999-2000) prices are taken. The share of primary sector (including agriculture, forestry and fishing) in the GDP, measuring growth of the respective sector over the years is denoted by PRI. The share of secondary sector (including mining \& quarrying, manufacturing, electricity, gas \& water supply and construction) in the GDP, measuring growth of the respective sector over the years is represented by SEC. The share of tertiary sector (including trade, hotels, transport \& communication, financing, insurance, real estate and business services along with community, social and personal services) in the GDP, measuring growth of the respective sector over the years is denoted by TER. The data have been taken from various issues of the Reserve Bank of India bulletin.

\subsection{Estimation Issues}

\section{Regression Analysis}

A simple regression model designed by the author is used to predict which of the three sectors is contributing more towards foreign investment inflows in the country for the time period 1996-97:Q1 to 2009-10: Q2.

The linear regression equation used here may be represented as:

$$
L n F I=\alpha+\beta_{1} L n P R I+\beta_{2} L n S E C+\beta_{3} L n T E R+\varepsilon
$$

where $\alpha$ is the constant term. LnPRI represents the primary sector's share in GDP (in logarithmic form), LnSEC denotes the secondary sector's share in GDP (in logarithmic form), LnTER denotes the tertiary sector's share in GDP (in logarithmic form) and LnFI represents foreign investment inflows (in logarithmic form) $\varepsilon$ is the error term. $\beta_{1}, \beta_{2}, \beta_{3}$ are the coefficients to be estimated.

The study uses a Granger causality test in a multivariate Vector Autoregressive (VAR) framework to examine causality between foreign investment inflows and sectoral growth pattern for the time period 199697:Q1 to 2009-10:Q2 (Table 1).

\section{Tests for Stationarity}

To test the stationarity of the variables ADF test, PP test and KPSS tests are performed.

\section{Tests for Causality}

The models used for testing Granger causality in a VAR framework at level form:

$$
\begin{aligned}
& \operatorname{LnFI}_{t}=\sum_{\mathrm{j}=1}^{\mathrm{p}} \alpha_{11, j} \operatorname{LnFI}_{t-j}+\sum_{\mathrm{j}=1}^{\mathrm{p}} \alpha_{12, j} \operatorname{LnPRI_{t-j}}+ \\
& \sum_{\mathrm{j}=1}^{\mathrm{p}} \alpha_{13, j} \operatorname{LnSEC_{t-j}}+\sum_{\mathrm{j}=1}^{\mathrm{p}} \alpha_{14, j} \operatorname{LnTER}_{t-\mathrm{j}}+\varepsilon_{l t}
\end{aligned}
$$

$$
\begin{aligned}
& \operatorname{LnPRI}_{t}=\sum_{\mathrm{j}=1}^{\mathrm{p}} \alpha_{21, j} \operatorname{LnPRI}_{t-\mathrm{j}}+\sum_{\mathrm{j}=1}^{\mathrm{p}} \alpha_{22, j} \operatorname{LnFI_{t-j}}+ \\
& \sum_{\mathrm{j}=1}^{\mathrm{p}} \alpha_{23, j} \operatorname{LnSEC_{t-j}}+\sum_{\mathrm{j}=1}^{\mathrm{p}} \alpha_{24, j} \operatorname{LnTER}_{t-j}+\varepsilon_{2 t}
\end{aligned}
$$

$$
\begin{aligned}
& \operatorname{LnSEC}_{t}=\sum_{\mathrm{j}=1}^{\mathrm{p}} \alpha_{31, j} \operatorname{LnSEC}_{t-j}+\sum_{\mathrm{j}=1}^{\mathrm{p}} \alpha_{32, j} \operatorname{LnFI_{t-j}+} \\
& \sum_{\mathrm{j}=1}^{\mathrm{p}} \alpha_{33, j} \operatorname{LnPRI}_{t-\mathrm{j}}+\sum_{\mathrm{j}=1}^{\mathrm{p}} \alpha_{34, j} \operatorname{LnTER}_{t-j}+\varepsilon_{3 t}
\end{aligned}
$$




$$
\begin{aligned}
& \operatorname{LnTER}_{t}=\sum_{\mathrm{j}=1}^{\mathrm{p}} \alpha_{41, j} \operatorname{LnTER}_{t-j}+\sum_{\mathrm{j}=1}^{\mathrm{p}} \alpha_{42, j} \operatorname{LnFI}_{t-j}+
\end{aligned}
$$

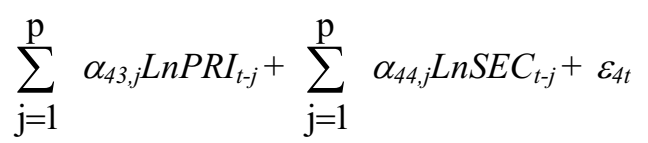

where LnFI, LnPRI, LnSEC and LnTER are the time series of foreign investment inflows, share of the primary sector, share of the secondary sector and share of the tertiary sector respectively in GDP (measuring growth of the respective sectors) and they are in the logarithm form. $\varepsilon_{1 t}, \varepsilon_{2}, \varepsilon_{3 t}$ and $\varepsilon_{4 t}$ are white noises. $\mathrm{p}$ is the lag length of VAR.

The Cointegration test is not feasible in this study. It is feasible only if the variables are non-stationary at their levels. From Engel and Granger's original definition, cointegration refers to variables that are integrated of the same order. In this study the variables are either I(0), I(1) or I(2) and not integrated of the same order. In other words, before testing the cointegration (i.e., to establish an existence or otherwise of a longterm equilibrium relationship) between two economic time series, say $\mathrm{X}$ and $\mathrm{Y}$, it is first necessary to test whether they are integrated of the same order. This suggests that it would not be feasible to consider the cointegration analysis, which implies that a long-run relationship does not exist between FI and the growth of the primary, secondary and tertiary sectors for the period of the study 1996-97: Q1 to 2009-10: Q2. The prerequisite for the Cointegration test is that the given variables should be I(1). In the absence of the above prerequisite in India's data series pertaining to FI and sectoral growth, the cointegration test has been omitted and short run Granger causality test is done.

\section{DISCUSSION OF RESULTS}

The results in Table 2 reveal that the secondary sector's share in GDP is significant at $1 \%$ level in explaining FI inflows and tertiary sector's share in GDP is significant at $1 \%$ in explaining FI inflows in India during the period 1996-97: Q1 to 200910: Q2. This signifies that growth in the secondary sector and tertiary sector affects foreign investment inflows in the host country. The $R^{2}$ value of 0.961714 is significant in explaining measurement of goodness of fit of the regression model. The small $p$ value $(0.00001)$ of the $F$ statistic reveals that the regression is significant. The study has employed various diagnostic tests viz., Jarque Bera normality test, Autoregressive Conditional Heteroskedasticty (ARCH) LM test and Ramsey RESET specification test to examine the validity and realiability of the regression model.

Jarque Bera test statistic (Table 3) is used for testing whether the residuals of the series are normally distributed. The null hypothesis is of a normal distribution - a small probability value leads to the rejection of the null hypothesis. Here the null hypothesis cannot be rejected ( $p$ value $=0.514513$ ) so it can be concluded that the residual series is normally distributed.

Ramsey's RESET test is general test for misspecification of functional form. The null hypothesis that the functional form is correctly specified is tested and the consequent $F$ statistic and the log likelihood ratios are reported. Both $F$ and $\chi^{2}$ versions of the test (Table 4) shows that there is noapparent non-linearity in the regression model and it can be concluded that the linear model for FI is appropriate. 
Table 1. VAR Lag Order Selection Criteria (LnFI, LnPRI, LnSEC and LnTER)

\begin{tabular}{|c|c|c|c|c|c|c|}
\hline Lag & Log L & LR & FPE & AIC & SC & HQIC \\
\hline 0 & 98.67392 & NA & $2.66 \mathrm{e}-07$ & -3.786957 & -3.633995 & -3.728708 \\
\hline 1 & 234.0005 & 243.5878 & $2.26 \mathrm{e}-09$ & -8.560020 & -7.795210 & -8.268776 \\
\hline 2 & 350.1641 & 190.5083 & $4.16 \mathrm{e}-11$ & -12.56656 & -11.18991 & -12.04233 \\
\hline 3 & 407.5529 & 84.93543 & $8.22 \mathrm{e}-12$ & -14.22212 & $-12.23361^{*}$ & -13.46488 \\
\hline 4 & 437.7782 & $39.89739^{*}$ & $4.96 \mathrm{e}-12^{*}$ & $-14.79113^{*}$ & -12.19078 & $-13.80090^{*}$ \\
\hline
\end{tabular}

*indicates lag order selected by the criterion

Table 2. Regression Results for the Time Period 1996-97:Q1 - 2009-10:Q2

\begin{tabular}{|c|c|c|c|c|c|c|c|}
\hline & Constant & LnPRI & LnSEC & LnTER & $R^{2}$ & $\bar{R}^{2}$ & F-statistic \\
\hline LnFI & $\begin{array}{l}-49.6586^{* * *} \\
(2.81381) \\
{[-17.6481]}\end{array}$ & $\begin{array}{l}0.008062 \\
(0.19019) \\
{[0.04238]}\end{array}$ & $\begin{array}{l}7.57938 * * * \\
(1.011597) \\
{[7.492502]}\end{array}$ & $\begin{array}{l}2.3852 * * * \\
(0.82719) \\
{[2.88357]}\end{array}$ & 0.9617 & 0.9594 & $\begin{array}{l}418.657 \\
(\mathrm{p} \text { value } \\
=0.00001)\end{array}$ \\
\hline
\end{tabular}

*** indicates significant at $1 \%$ level. Standard errors in ( ) \& t-statistics in [ ]

Table 3. Jarque Bera test

\begin{tabular}{|c|c|c|c|c|}
\hline $\begin{array}{c}\text { Diagnostic } \\
\text { test }\end{array}$ & Purpose & Test Statistic & Probability & Conclusion \\
\hline $\begin{array}{c}\text { Jarque Bera } \\
\text { test }\end{array}$ & Normality & 1.329070 & 0.514513 & $\begin{array}{c}\text { Normally } \\
\text { distributed }\end{array}$ \\
\hline
\end{tabular}

Table 4. Ramsey RESET Test

\begin{tabular}{|c|c|l|l|}
\hline$F$-statistic & 1.914629 & Prob. $F(1,49)$ & 0.1727 \\
\hline Log likelihood ratio & 2.069819 & Prob. Chi-Square(1) & 0.1502 \\
\hline
\end{tabular}

The ARCH test is a Lagrange multiplier (LM) test for autoregressive conditional heteroskedasticity $(\mathrm{ARCH})$ in the residuals. The ARCH test is one of a joint null hypothesis that all $\mathrm{q}$ lags of the squared residuals have co-efficient values that are not significantly differently form zero. The $F$ statistic is an omitted variable test for the joint significance of all lagged squared residuals. The $\mathrm{Obs}^{*} \mathrm{R}$-squared statistic is Engle's LM test statistic, computed as the number of observations multiplied by the coefficient of multiple correlation and is asymptotically distributed as a $\chi^{2}(q)$. (Table $5)$ Both the $F$-version and the LM-statistic are not quiet significant and there is no arch effects in the residuals of the estimated model. GDP sector share is presented in Figure 1.

Finally CUSUM and CUSUMSQ tests are used to check the stability of the parameters in the model. The null hypothesis of parameter stability cannot be rejected at the $5 \%$ level of significance as the cumulated sum stays inside the $95 \%$ confidence band in case of both CUSUM and CUSUMSQ tests. The CUSUM test indicates stability in the equation during the sample period because the line (blue) lies within the $5 \%$ critical lines (Figure 2). The CUSUM of squares test

Table 5. Heteroskedasticity Test - ARCH

\begin{tabular}{|c|c|c|c|}
\hline$F$-statistic & 0.114530 & Prob. $F(1,51)$ & 0.7364 \\
\hline Obs*R-squared & 0.118755 & Prob. Chi-Square(1) & 0.7304 \\
\hline
\end{tabular}




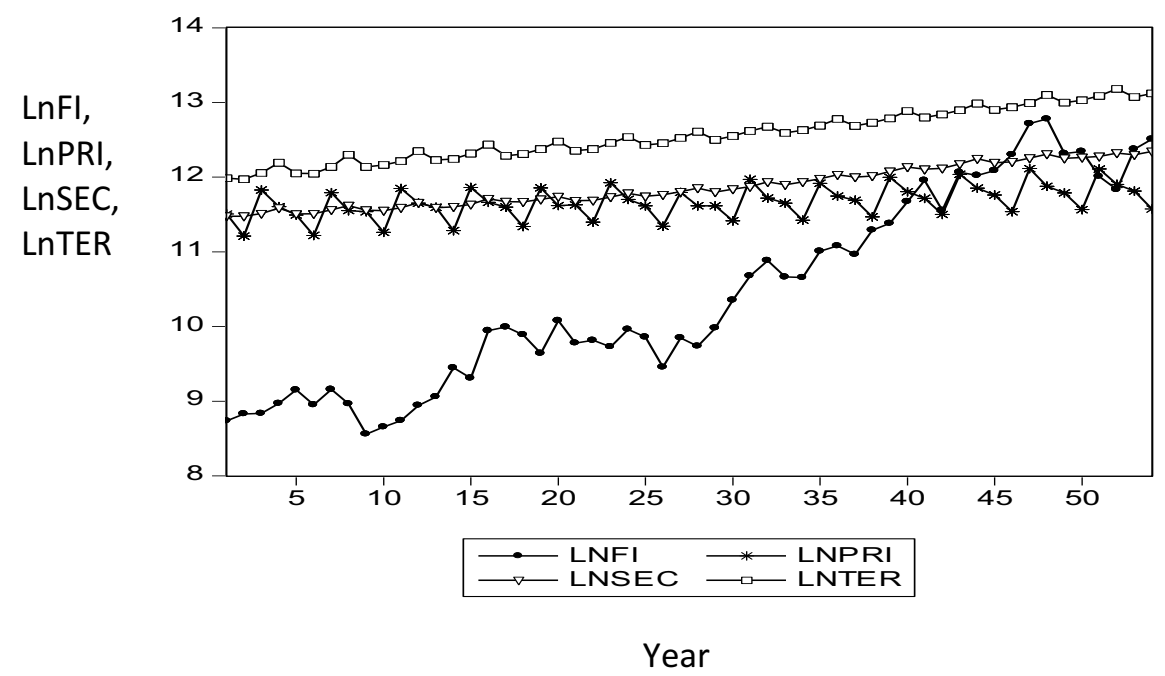

Figure 1. Logarithmic values of foreign investment inflows, primary sector's share to GDP, secondary sector's share to GDP, tertiary sector's share to GDP

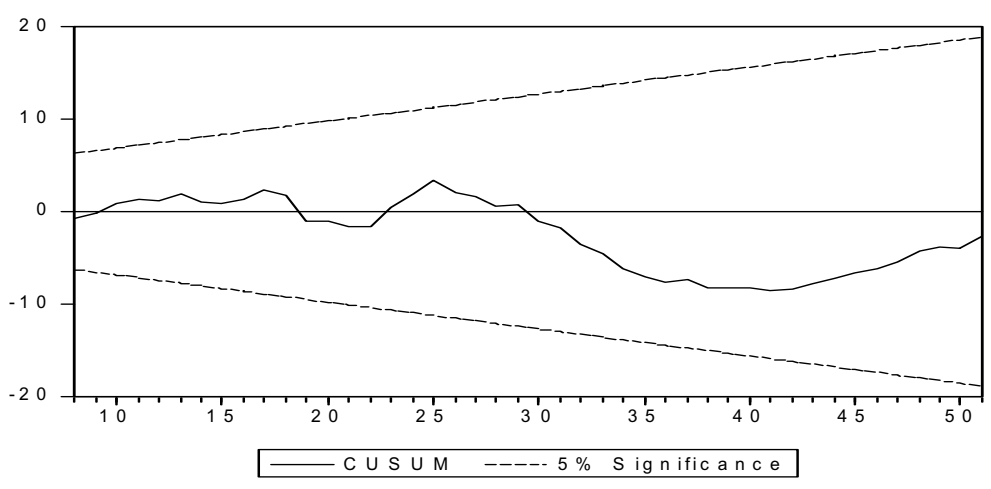

Figure 2. Diagrammatic representation of CUSUM Test

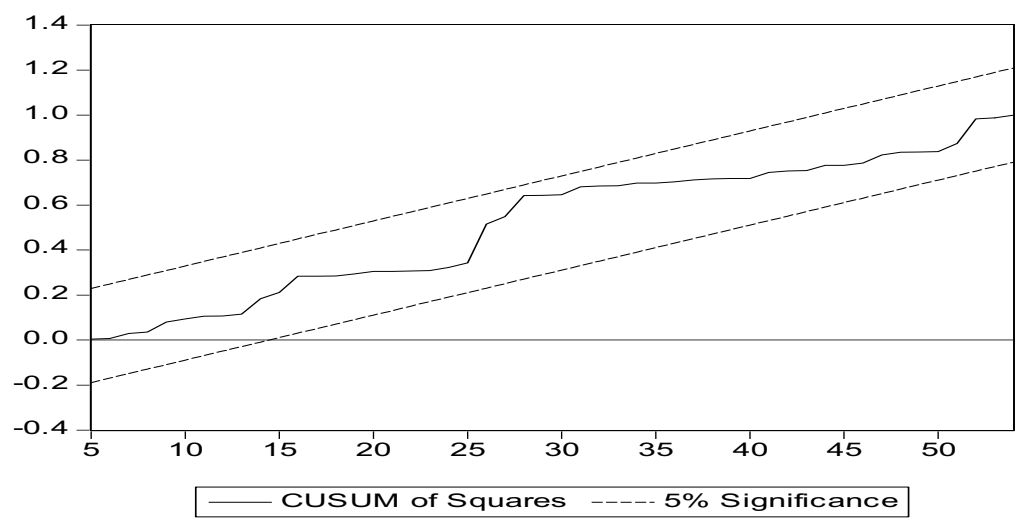

Figure 3. Diagrammatic representation of CUSUMSQ Test 
shows that the cumulative sum of the squares is within the $5 \%$ significance lines, suggesting that the residual variance is stable (Figure 3).

\section{Test for Stationarity}

Table 6 and Table 7 represent the results of ADF, PP tests of unit root respectively by lag length chosen based on minimum values of Schwarz information criterion (SIC).
KPSS test is also performed on both the level and first differences of the lagged variables.

In Table 6 the unit root test is done assuming the data set having a trend and Table 7 represents the data not having a trend. It is seen as per Table 6 that the variable foreign investment inflows is an I(1) process according to ADF, PP and KPSS tests. The variable PRI is an I(1) process according to ADF, KPSS test but is an I(0) process according to PP test. The variable

Table 6. Test of Unit Root Hypothesis without Trend (1996-97:Q1 to 2009-10:Q2)

\begin{tabular}{|c|c|c|c|c|c|c|c|}
\hline & & \multicolumn{2}{|l|}{ ADF Statistic } & \multicolumn{2}{|l|}{ PP Test } & \multicolumn{2}{|l|}{ KPSS } \\
\hline Series & & Test Statistic & Lags & Test Statistic & Lags & Test Statistic & $\begin{array}{l}\text { Band } \\
\text { width }\end{array}$ \\
\hline \multirow[b]{2}{*}{ LnFI } & Level & -0.44574 & 0 & -0.44574 & 0 & $0.83457 * * *$ & 6 \\
\hline & $\begin{array}{l}\text { First } \\
\text { Difference }\end{array}$ & $-8.52138 * * *$ & 0 & $-8.52138 * * *$ & 0 & 0.061344 & 1 \\
\hline \multirow[b]{2}{*}{ LnPRI } & Level & 0.108848 & 8 & $-85.6542 * * *$ & 8 & $0.94408 * * *$ & 4 \\
\hline & $\begin{array}{l}\text { First } \\
\text { Difference }\end{array}$ & $-2.884514 * *$ & 7 & $-209.758 * * *$ & 7 & 0.345592 & 11 \\
\hline \multirow[b]{2}{*}{ LnSEC } & Level & 0.417082 & 4 & 0.778940 & 4 & $0.86455 * * *$ & 6 \\
\hline & $\begin{array}{l}\text { First } \\
\text { Difference }\end{array}$ & -2.174470 & 3 & $-44.2354 * * *$ & 3 & 0.272891 & 11 \\
\hline \multirow[t]{2}{*}{ LnTER } & Level & 1.415755 & 4 & -0.404592 & 4 & $0.87989 * * *$ & 6 \\
\hline & $\begin{array}{l}\text { First } \\
\text { Difference }\end{array}$ & -2.473573 & 4 & $-105.256^{* * *}$ & 4 & 0.257110 & 11 \\
\hline
\end{tabular}

(a)The critical values are those of McKinnon (1991)

(b) ${ }^{* *}, * *$ and $*$ represent the rejection of null hypothesis at $1 \%, 5 \%$ and $10 \%$ levels of significance respectively.

Table 7. Test of Unit Root Hypothesis with Trend (1996-97:Q1 to 2009-10:Q2)

\begin{tabular}{|c|c|c|c|c|c|c|c|}
\hline & & \multicolumn{2}{|c|}{ ADF Statistic } & \multicolumn{2}{c|}{ PP Test } & \multicolumn{2}{c|}{ KPSS } \\
\hline \multirow{2}{*}{ Series } & & Test Statistic & Lags & Test Statistic & Lags & Test Statistic & $\begin{array}{c}\text { Band } \\
\text { width }\end{array}$ \\
\hline \multirow{3}{*}{ LnFI } & Level & -2.896910 & 0 & -2.896910 & 0 & $0.13232 * * *$ & 5 \\
\cline { 2 - 8 } & $\begin{array}{c}\text { First } \\
\text { Difference }\end{array}$ & $-8.46169 * * *$ & 0 & $-8.46169 * * *$ & 0 & 0.043105 & 1 \\
\hline \multirow{2}{*}{ LnPRI } & Level & -1.570167 & 8 & $-51.7343 * * *$ & 8 & $0.14112^{* * *}$ & 11 \\
\cline { 2 - 8 } & $\begin{array}{c}\text { First } \\
\text { Difference }\end{array}$ & -2.871645 & 7 & $-253.478^{* * *}$ & 7 & 0.278100 & 11 \\
\hline \multirow{3}{*}{ LnSEC } & Level & -1.921142 & 4 & -2.806372 & 4 & $0.22206^{* * *}$ & 5 \\
\cline { 2 - 8 } & $\begin{array}{c}\text { First } \\
\text { Difference }\end{array}$ & -2.263210 & 3 & $-41.2156^{* * *}$ & 3 & 0.148913 & 11 \\
\hline \multirow{2}{*}{ LnTER } & Level & $-3.557074 * *$ & 10 & $-39.6120^{* * *}$ & 10 & $0.12215^{* * *}$ & 14 \\
\cline { 2 - 8 } & $\begin{array}{c}\text { First } \\
\text { Difference }\end{array}$ & $-3.957665^{* *}$ & 3 & $-28.5945^{* * *}$ & 3 & $0.25597 * * *$ & 11 \\
\hline
\end{tabular}

(a)The critical values are those of McKinnon (1991)

(b) ${ }^{* * *}, * *$ and $*$ represent the rejection of null hypothesis at $1 \%, 5 \%$ and $10 \%$ levels of significance respectively. 
SEC is an I(2) process according to ADF test but is an I(1) process according to PP and KPSS test. The variable TER is an I(2) process according to ADF test but is an I(1) process according to PP and KPSS test.

In Table 7 it is seen that the variable foreign investment inflows is an I(1) process according to ADF, PP and KPSS tests. The variable $\mathrm{PRI}$ is an $\mathrm{I}(2)$ process according to ADF test, is an $\mathrm{I}(0)$ process according to PP test and is an I(1) process according to KPSS test. The variable SEC is an I(2) process according to ADF test, is an I(1) process according to PP test and KPSS test. The variable TER is an $\mathrm{I}(0)$ process according to ADF and PP test, is an I(2) process according to KPSS test.

\section{Causality Test}

Although it has been concluded that there is no cointegration (i.e. long run relationship between the variables), it does not mean absence of causality or relation in the short term. In cases where FI inflows and growth in primary, secondary and tertiary sector do not move together in the long run (i.e., no cointegration) it is possible for the variables to affect each other in the short run. Since the variables in a VAR are not cointegrated the Granger causality tests can be conducted using a standard F distribution. Since the variables are either $\mathrm{I}(0)$, or $\mathrm{I}(1)$ or $\mathrm{I}(2)$, the Granger causality test can be performed at the level form in the framework of VAR model. The VAR estimates are computed taking each one of them once as the dependent variable and the other three as the independent variables. The null hypothesis is accepted or rejected on the basis of " $F$ statistic" to determine the joint significance of the restrictions under the null hypothesis. The lag length is justified by a minimum of Final prediction error (FPE), Schwarz information criterion (SIC) and Likelihood ratio test statistics. The test result suggests lag order of 4 as optimal lag as seen in Table 1. In Table 8 the null hypothesis "LnPRI does not Granger cause LnFI" cannot be rejected ( $p$ value 0.2802 ), which indicates that the coefficients of the lags of LnPRI are jointly zero in the equation for LnFI and it can be concluded that growth in the primary sector growth does not cause foreign investment inflows. The null hypothesis "LnFI does not Granger cause LnPRI" may

Table 8. Pairwise Granger Causality Tests

\begin{tabular}{|l|c|c|r|}
\hline Sample: 1-54 & \\
\hline Lags: 4 & Obs & F-Statistic & Prob \\
\hline Null Hypothesis: & 50 & 1.31581 & 0.2802 \\
\hline LnPRI does not Granger Cause LnFI & & 2.27202 & 0.0779 \\
\hline LnFI does not Granger Cause LnPRI & 50 & 5.93664 & 0.0007 \\
\hline LnSEC does not Granger Cause LnFI & 50 & 3.68539 & 0.0118 \\
\hline LnFI does not Granger Cause LnSEC & 50 & 4.76831 & 0.0030 \\
\hline LnTER does not Granger Cause LnFI & & 20.8061 & 0.0000 \\
\hline LnFI does not Granger Cause LnTER & 50 & 4.75154 & 0.0030 \\
\hline LnSEC does not Granger Cause LnPRI & 5.093 & 0.0283 \\
\hline LnPRI does not Granger Cause LnSEC & 5.09583 & 0.0020 \\
\hline LnTER does not Granger Cause LnPRI & 50 & 16.5118 & 0.0000 \\
\hline LnPRI does not Granger Cause LnTER & 4.84521 & 0.0027 \\
\hline LnTER does not Granger Cause LnSEC &
\end{tabular}


be rejected ( $\mathrm{p}$ value 0.0779 ) and it can be concluded that foreign investment inflows causes growth in the primary sector. The null hypothesis "LnSEC does not Granger cause LnFI" may be rejected ( $p$ value 0.0007 ) and it can be concluded that growth in the secondary sector causes foreign investment inflows. The null hypothesis "LnFI does not Granger cause LnSEC" may be rejected ( $p$ value 0.0283 ) and it can be concluded that foreign investment inflows causes growth in the secondary sector. It is seen that bidirectional causality is observed between secondary sector growth and foreign investment inflows. The null hypothesis "LnTER does not Granger cause LnFI" may be rejected ( $\mathrm{p}$ value 0.0118 ) and it can be concluded that growth in the tertiary sector causes foreign investment inflows. The null hypothesis "LnFI does not Granger cause LnTER" cannot be rejected ( $\mathrm{p}$ value 0.3463 ) and it can be concluded that foreign investment inflows does not cause growth in the tertiary sector. The null hypothesis "LnSEC does not Granger cause LnPRI" may be rejected ( $p$ value 0.0030 ) and it can be concluded that secondary sector growth causes growth in the primary sector. The null hypothesis "LnPRI does not Granger cause LnSEC" may be rejected ( $p$ value 0.0000) and it can be concluded that primary sector growth causes growth in the secondary sector. So, birectional causality is observed between the growth of these two sectors namely secondary and primary sector.

The null hypothesis "LnTER does not Granger cause LnPRI" may be rejected ( $p$ value 0.0030 ) and it can be concluded that tertiary sector growth causes growth in the primary sector. The null hypothesis "LnPRI does not Granger cause LnTER" may be rejected ( $p$ value 0.0020) and it can be concluded that primary sector growth causes growth in the tertiary sector. So, bidirectional causality is observed between the growth of primary and tertiary sectors. The null hypothesis "LnTER does not Granger cause LnSEC" may be rejected ( $p$ value 0.0000) and it can be concluded that tertiary sector growth causes growth in the secondary sector. The null hypothesis "LnSEC does not Granger cause LnTER" may be rejected ( $p$ value 0.0027 ) and it can be concluded that secendary sector growth causes growth in the tertiary sector. So, bidirectional causality is observed between the growth of secondary and tertiary sectors.

\section{CONCLUSION}

Bidirectional causality is observed between foreign investment inflows and secondary sector growth and it is seen that tertiary sector growth causes foreign investment inflows. The impact of foreign investment inflows depends not only on the characteristics of the sectors but also on the linkage potential of these sectors with the rest of the economy. Foreign investment inflows to the agricultural sector (primary sector) is mostly capital intensive and the scope and linkages between foreign companies and the rest of the economy is often limited, whereas foreign investment inflows in manufacturing sector may have a larger impact in the economy through a broad range of potential linkage intensive activities. Services sector (tertiary sector) includes a wide range of different activities such as finance, infrastructure (electricity, water and telecommunications), wholesale and retail, real estate as well as tourism. Foreign investment inflows to this sector is mostly to serve the domestic market and hence create potential forward linkages for 
the sectors, which are quite strong, while backward linkages may vary by industry.

Major part of the foreign investment inflows in agricultural sector comes as megaprojects with huge capital inflows to a country. These projects have limited linkages to domestic economy as they usually use few local intermediate goods and are mostly export-oriented. Not only do foreign investment flows to this sector tend to be more volatile but also most investments are large and sensitive to world commodity prices. Foreign investment inflows induces growth of some of the primary sector such as petroleum, mining and agriculture where revenue can be generated and few policymakers feel that investment in the primary sector is conducive to creating employment. It is seen from the results that growth of the primary sector does not seem to influence foreign investment inflows and primary sector investment fails in countries with no centralized political control or fundamental macroeconomic dislocation.

Foreign firms prefer to invest in the manufacturing sector, rather than export to a country for either efficiency seeking or market seeking or a combination of both. In case of efficiency seeking, foreign investment is more likely to bring in the technology and know-how that is compatible with the country. It usually generates significant employment and provides training. Foreign firms usually use some level of local intermediate products. Hence, foreign investment has significant horizontal and backward linkages. In addition, foreign company exports increase the total exports as also the foreign currency receipts of the country. Foreign investment in manufacturing is expected to have significant impact in the recipient economy. Not only the growth of the secondary sector causes foreign investment inflows to the country, but also the foreign investment inflows enhances growth of the secondary sector. It seems that foreign investment inflow in this sector will yield statistically identifiable benefit. Transfer of technology and management know-how, introduction of new processes and employee training tend to relate to the manufacturing sector rather than the primary sector. Policymakers tend to focus on secondary sector investment believing that manufacturing investment can bring jobs to absorb labor from lowerproductivity sectors, an especially important among emerging markets where agricultural employment remains important.

Output is not tradable in the service sector like that of the agricultural and manufacturing sectors; so much of the foreign investment in the form of FDI in the services sector is market seeking where forward linkages for foreign investment are well defined and potential impact of foreign investment in the sector is immense. In the highly capital-intensive infrastructure sector, foreign investment can provide the necessary funding and technology to improve capacity to meet increasing demand, as well as improve the quality and lower the cost of the services. Foreign investment in the banking sector can also have an important impact on both the efficiency and stability of the banking system through increased competition and increased access to global financial markets. If foreign investment in the sector improves services in the country, all other associated sectors will be positively affected. India is yet to realize the benefits of foreign investment inflow in the services sector and gradually more capital flows are happening in this sector. The growth of the tertiary sector (services) influences foreign investment inflows and draws more foreign 
capital to the country. However, foreign investment in the services sector may also have significant negative effects. As the market structure is less competitive and there is capital intensity of many industries in this sector, foreign investors command superior market power. So much of the benefit of foreign investment inflows in the tertiary sector is yet to be realized.

While openness did not appear to matter for primary or secondary sector, it is very important for foreign investment inflows in the services sector when the real effective exchange rate is controlled. Apart from opening up trade and investment the governments may need to set new competition rules. Strong, independent regulatory agencies and competition control authorities are required for performing these tasks although such institutions may be costly to set up and run. In developing countries technical assistance and capacity building are important, as these institutions require sophisticated skills, which brings a great challenge in front of these countries.

It is also observed that growth in India's industrial sector growth and growth in the services sector influence each other. India's manufacturing sector growth to a large extent depends on growth in the services sector such as transportation and electricity. Moreover, India's world-class knowledge-based services are also increasingly assuming importance for the inputs they provide for other sectors of the Indian domestic economy (such as manufacturing, retail and logistics) thereby improving productivity in those sectors and further enhancing growth prospects. The role of the qualitative and institutional is also important. Liberalizing labor markets and measures to increase financial deepening could attract more secondary foreign investment inflows into emerging markets, though these effects are weaker among advanced economies. A more independent judiciary and better infrastructure appear to attract more services foreign investment inflows to both types of economies.

\section{ПРИЛИВ СТРАНИХ ИНВЕСТИЦИЈА И РАСТ ПО СЕКТОРИМА У ИНДИЈИ - ЕМПИРИЈСКА СТУДИЈА}

\section{Mousumi Bhattacharya}

\section{Извод}

Овај рад се бави одређивањем односа између прилива страних инвестиција и начина раста по секторима у три основна привредна сектора у Индији, током периода након либерализације (1996 до 2009). Одређена је дводирекциона повезаност између страних инвестиција и секторског раста, применом Грангеровог теста корелације у вишеваријантном окружењу. Примећено је да раст терцијалног сектора генерише прираст нових страних инвестиција. Такође је урађена регресиона анализа на истој полазној бази података, која је такође показала да раст терцијаног сектора доводи до пораста директних страних инвестиција након реформа из 1990-тих. 


\section{References}

Alfaro, L. (2003). Foreign Direct Investment and Growth: Does the Sector Matter? Boston, MA, Harvard Business School, Mimeo.

Chakraborty, C., \& Nunnenkamp, P. (2008). Economic Reforms, FDI and Economic growth in India: A Sector Level Analysis. World Development, 36(7), 11921212.

Findlay, R. (1978). Relative Backwardness, Direct Foreign Investment, and the Transfer of Technology: A Simple Dynamic Model. The Quarterly Journal of Economics, 92(1), 1-16. doi:10.2307/1885996

Hirschman, A.O. (1958). The Strategy of Economic Development. New Haven, Conn: Yale University Press.

Kathuria, V. (2002). Liberalisation, FDI, and productivity spillovers--an analysis of Indian manufacturing firms. Oxford Economic Papers, 54(4), 688-718. doi:10.1093/oep/54.4.688

Kokko, A. (1994). Technology, Market Characteristics and Spillovers. Journal of Development Economics, 43, 279-293.

Lo, C., \& Liu, B. (2009). Why India is mainly engaged in offshore service activities, while China is disproportionately engaged in manufacturing? China Economic Review, 20, 236-245.

MacKinnon, J.G. (1991). Critical Values for Co-integration Tests. Pp 267-276 in R.F. Engle and C.W.J. Granger (Eds.), Long Run Economic Relationships: Readings in Cointegration, Oxford: Oxford University Press.

Rodriguez-Clare, A. (1996). Multinationals, Linkages and Economic Development. American Economic Review, $86,852-873$.
United Nations Conference on Trade and Development [UNCTAD] (2001). World Investment Report 2001: Promoting Linkages, Geneva and New York: UNCTAD.

Wang, J.Y., \& Blomstrom, M. (1992). Foreign Investment and Technology Transfer; A Simple Model. European Economic Review, 36(1), 137-155. 